GEOLOGICAL SURVEY CIRCULAR 124

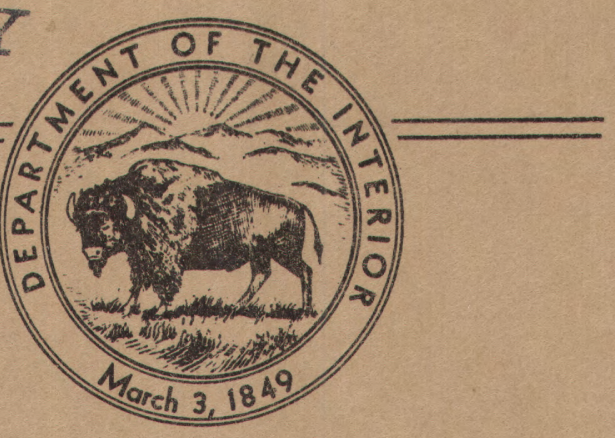

July 1951

\title{
FIELD METHOD FOR THE DETERMINATION OF MOLYBDENUM IN PLANTS
}

By

Laura E. Reichen and F. N. Ward 
UNITED STATES DEPARTMENT OF THE INTERIOR

Oscar L. Chapman, Secretary

GE OLOGICAL SURVEY

W. E. Wrather, Director

Washington, D. C.

Free on application to the Geological Survey, Washington 25, D. C. 


\section{FIELD METHOD FOR THE DETERMINATION OF MOLYBDENUM IN PLANTS}

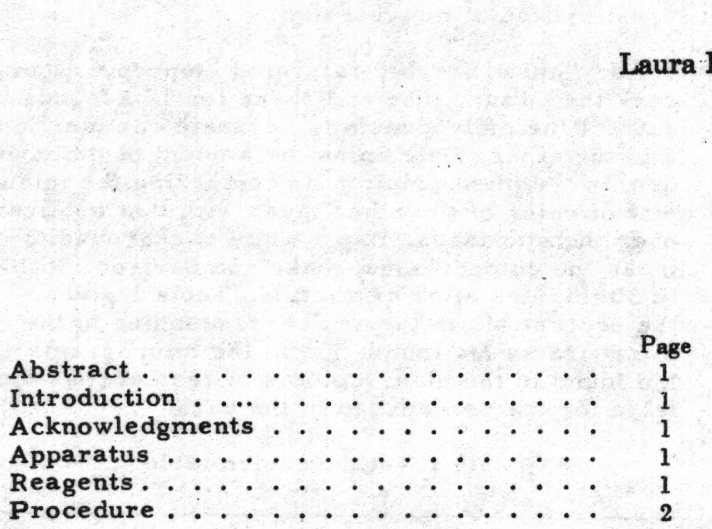

ABSTRACT

Fresh plant material is ashed directly by heating in nickel or platinum dishes over a -flame. An acid solution of 25 milligrams of ash is treated with stannous chloride and potassium thiocyanate. The amber-colored molybdenum thiocyanate complex ion is extracted with isopropyl ether, and the intensity of the color of the ether layer over a sample solution is compared with the ether layer over standard molybdenum solutions treated similarly. Field determinations can be made quickly and the method requires no special equipment. As little as 0.25 microgram or 0.001 percent molybdenum can be determined in plant ash.

\section{INTRODUCTION}

This method for the determination of molybde num was developed for use in the search for mineralized areas and ore deposits by chemical studies of vegetation. It is a modification of the thiocyanate-stannous chloride method, modified for easy use in the field.

According to ter Meulen and Ravenswaag (1935), Bertrand (1940), Ferguson and others (1940), Barshad (1948), Mitchell (1948), and Robinson and Edgington (1948), molybdenum in plants varies from less than 0.0001 to 0.04 percent in the dry plant. This would be roughly 0.002 to 0.1 percent molybdenum on an ash basis.

The analysis of plants for geochemical prospecting purposes need not be very accurate. Small variations in molybdenum content, caused by such factors as the health of the plant and variation in soil moisture, are not significant in prospecting. Failure of a method to detect these small differences is an advantage; otherwise, they might be attributed to differences in molybdenum content of the soil. The method which follows is an attempt to meet the sensitivity, range of molybdenum content, and the accuracy deemed desirable for a field method for geochemical prospecting.

By

\section{CONTENTS}

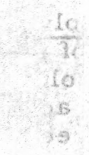

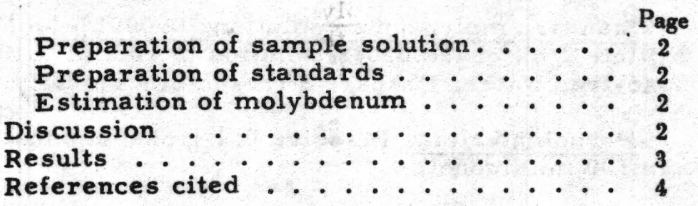

\section{ACKNOWLEDGMENTS}

Some of the plant samples for this work were obtained from Mr. W. O. Robinson of the Bureau of Plant Industry, and the remainder were collected by Mrs. Helen L. Cannon of the Geological Survey.

\section{APPARATUS}

Gasoline stove. Coleman "GI" pocket stove is suitable for ashing samples.

Balance. Roller-Smith, Model C, 0 to $75 \mathrm{mg}$, is suitable to weigh the samples. A metal-free (lucite) scoop, previously calibrated by weighing a measured amount of pulverized plant ash, can also be used.

Culture tubes. $16 \times 150 \mathrm{~mm}$, pyrex, calibrated at $5 \mathrm{ml}$.

Dishes. Evaporating, $100 \mathrm{ml}$ capacity, platinum or nickel.

Test tube rack. Capacity 24 test tubes.

Glass pestle. Pyrex glass rod flattened on one end (about $10 \mathrm{~mm}$ ) to use as a pestle for grinding and mixing ash.

Scoop. Metal-free, $0.25 \mathrm{ml}$ capacity, to meas ure about $0.1 \mathrm{~g} \mathrm{\textrm {LNO } _ { 3 }}$.

\section{REAGENTS}

All reagents should be analytical reagent grade.

Hydrochloric acid, conc. Sp gr 1.19 .

Hydrochloric acid, $1 \mathrm{M}$. Dilute $8.5 \mathrm{ml}$ conc HCl, sp $\mathrm{gr}^{\mathrm{r}} 1.19$, to $100 \mathrm{ml}$ with Mo-free water.

Ammonium hydroxide, $1 \mathrm{M}$. Dilute $6.6 \mathrm{ml}$ conc $\mathrm{NH}_{4} \mathrm{OH}, \mathrm{sp} \mathrm{gr} 0.90$, to $100 \mathrm{ml}$ with Mo-free wáter. 


\section{Lithium nitrate.}

Potassium nitrate. $10 \mathrm{~g} \mathrm{KNO}_{3}$ in $100 \mathrm{ml}$ solution.

Potassium thiocyanate. $5 \mathrm{~g} \mathrm{KSCN}$ in $100 \mathrm{ml}$ solution.

Stannous chloride. $10 \mathrm{~g} \mathrm{SnCl} 2 \cdot 2 \mathrm{H}_{2} 0$ dissolved in $100 \mathrm{ml} 2 \mathrm{M} \mathrm{HCl}$. Filter the solution if it is not entirely clear. The addition of tin promotes stability, but fresh solutions should be prepared weekly.

Standard molybdenum solution $0.01 \%$ Mo. Dissolve $.075 \mathrm{~g}$ of pure $\mathrm{MOO}_{3}$ in a few millileters of dilute $\mathrm{NaOH}$ solution, dilute with Mo-free water, make slightly acid with $\mathrm{HCl}$, and make up to 500 $\mathrm{ml}$ with Mo-free water.

Standard molybdenum solution, $0.0002 \%$ Mo. Dilute $2 \mathrm{ml}$ of the $0.01 \%$ solution to $100 \mathrm{ml}$ with Mo-free water. Prepare a fresh solution daily.

Phenolphthalein. Dissolve $0.1 \mathrm{~g}$ phenolphthalein in $100 \mathrm{ml}$ alcohol.

Water. Pass tap water through a resin demineralizer, such as the Bantam Demineralizer manufactured by Barnstead Still and Sterilizer Co.

Isopropyl ether. Practical grade, free of peroxides. Saturate the ether with $\mathrm{SnCl}_{2}$ and $\mathrm{KSCN}$ by shaking with a solution containing equal volumes of these reagents equivalent to $10 \%$ of the volume of ether. To detect peroxides, vigorously shake $5 \mathrm{ml}$ of isopropyl ether with $5 \mathrm{ml}$ of an acidified aqueous solution of $\mathrm{KI}$. Reject the ether if the KI solution does not remain practically colorless.

\section{PROCEDURE}

Preparation of sample solution--Ash the fresh plant material by heating in a platinum or nickel dish directly over the flame of the burner. Stir occasionally during the ashing to facilitate burning. After glowing ceases, remove the dish from the burner and allow the ash to cool. Pulverize the ash with a glass pestle and mix thoroughly.

Weigh out $25 \mathrm{mg}$ of ash and transfer to a calibrated culture tube. Add a scoop of $\mathrm{LiNO}_{3}$ (about $0.1 \mathrm{~g}$ ), and fuse over a low flame holding the mouth of the tube away from the operator. Roll the test tube as the melt cools so that a thin layer is formed on the sides of the tube to facilitate solution. Add $1 \mathrm{ml}$ of $1 \mathrm{M} \mathrm{HCl}$ to dissolve the melt. Add a drop of phenolphthalein, and then add $1 \mathrm{M} \mathrm{NH}_{4} \mathrm{OH}$ until the solution is faintly pink; avoid an excess of $\mathrm{NH}_{4} \mathrm{OH}$. Make the volume up to $5 \mathrm{ml}$ with water.

Preparation of standards--Pipette the $0.0002 \%$ standard Mo solution into separate culture tubes to prepare a series of standard solutions differing by 0.5 microgram over a range from 0 to 5 micrograms. Add $1 \mathrm{ml} \mathrm{KNO} 3$ solution to each tube and make the volume up to $5 \mathrm{ml}$ with water.

Estimation of molybdenum--To both the standard and plant solutions add $0.6 \mathrm{ml}$ conc

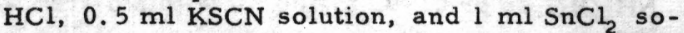
lution, shaking after each addition. Let the solutions stand for about 1 minute. Make a preliminary comparison of the sample solutions with the 5 microgram standard. Discard any samples which are obviously darker and replace with an aliquot of a $10 \mathrm{mg}$ sample of ash prepared as follows:
Fuse the replacement sample with $\mathrm{LiNO}_{3}$ and dissolve the melt in $1 \mathrm{M} \mathrm{HCl}$ as before. Make the volume up to $5 \mathrm{ml}$ with water. Pipette 1 $\mathrm{ml}$ ( $2 \mathrm{mg}$ ) of this solution into another culture tube, add phenolphthalein, and then $1 \mathrm{M}$ $\mathrm{HN}_{4} \mathrm{OH}$ until the solution is faintly pink. Make the volume up to $5 \mathrm{ml}$ with water; add the conc $\mathrm{HCl}, \mathrm{KSCN}$ and $\mathrm{SnCl}_{2}$ to this aliquot for the estimation of molybdenum.

Add $1 \mathrm{ml}$ of freshly saturated isopropyl ether, cork the culture tube and shake for 15 seconds to extract the molybdenum thiocyanate complex ion into the ether. Determine the amount of molybde num in the plant solution by comparing the intensity of color of the ether layer with that obtained over the standards. Use a white background to make the comparisons; make comparisons within 30 minutes after extraction. Table 1 gives the percent Mo in the ash corresponding to the micrograms Mo found. From the micrograms Mo found in the plant (column 1) read across the table for the percent Mo in the ash.

Table 1.--Conversion table

\begin{tabular}{l|c|c}
\hline \multirow{2}{*}{$\begin{array}{l}\text { Micrograms } \\
\text { Mo found }\end{array}$} & \multicolumn{2}{|c}{ Percent Mo in ash } \\
\cline { 2 - 3 } & $25 \mathrm{mg}$ ash sample & $2 \mathrm{mg}$ ash sample \\
\hline & & \\
\hline $.1-0.3$ & 0.001 & 0.012 \\
$.4-.6$ & .002 & .025 \\
$7-.8$ & .003 & .037 \\
$9-1.0$ & .004 & .050 \\
1.5 & .006 & .075 \\
2.0 & .008 & .100 \\
2.5 & .010 & .125 \\
3.0 & .012 & .150 \\
3.5 & .014 & .175 \\
4.0 & .016 & .200 \\
4.5 & .018 & .225 \\
5.0 & .020 & .250 \\
\hline
\end{tabular}

\section{DISCUSSION}

For rapid determination in the field the plant is ashed before it has been dried. This necessitates the use of the weight of ash as the basis for the calculation of the molybdenum present. In reporting on the ash-basis rather than the more customary dry-basis, care must be taken that misleading results due to contaminated samples are not reported. Since the components of soil contamination (that is, the ferric oxide, silica, etc) do not change weight in the ashing, they tend to dilute the ash from the plant. Consequently, the effect of soil contamination is greater when the results are reported on the ash basis than when they are reported on the dry-plant basis. Soil contamination can be detected quite easily in this procedure. The lithium nitrate fusion, which is used to destroy residual carbon in the ash, does not appreciably attack the soil minerals. Their presence is shown by undecomposed particles in the bottom of the test tube after the melt from the fusion has been dissolved.

The laboratory results in table 2 were obtained from samples ashed at a controlled temperature, and the field method of ashing (in platinum) was used to obtain the results by the field-method. Such errors as would occur as a result of uncontrolled burning or ashing are included therefore in the field results. Since the overall differences obtained by the two methods are small, the errors due to the field method of ashing are 
also small. Equally satisfactory results can be obtained on ash prepared in either nickel or platinum dishes. The ignition in platinum is somewhat quicker, but platinum is expensive for field equipment.

With ethyl either a good separation can be obtained from all elements that interfere in the stannous chloride-thiocyanate method, with the exception of vanadium, tungsten, and rhenium (Sandell, 1950). Isopropyl ether has been successfully substituted for ethyl ether in the analysis of soils (Ward, in press), plants (Evans and others, 1950), and phosphate rock (Robinson, 1948). Isopropyl ether is preferable because it is less volatile than ethyl ether. It has the added advantage that, under the conditions of this test, the color of the ether layer is not affected by as much as 200 micrograms of vanadium. Moreover, it is unlikely that plants will contain enough tungsten or rhenium to affect the results. The carbon is destroyed because it tends to coat the organic layer and makes colorimetric readings difficult.

Color differences adequate for making readings can be detected in solutions containing 0.25 to 5 micrograms of molybdenum in a volume of 1 milliliter of isopropyl ether. Thus, the readable range covers only one order of magnitude whereas the range of molybdenum in plants $(0.002-0.1$ percent) covers two orders of magnitude. Extracting with 2 milliliters of ether merely shifted the readable range upward slightly ( $i$ to 8 micrograms). Decreasing the intensity of color to match the standards by diluting the 1 milliliter of ether extract also failed. It is necessary to reduce the amount of molybdenum being extracted to 5 micrograms or less by using a smaller sample of ash or by using an aliquot of the ash solution. When an aliquot is used, the aliquot must be taken before the adjustment of the acidity and the addition of thiocyanate and stannous chloride.

\section{RESULTS}

Molybdenum determinations were made on samples of plants by the proposed field method and a laboratory method to ascertain the merits of the field method. The ash for the laboratory method was made by ignition of air-dried, ground material in a muffle furnace at 450 degrees; the ash was dissolved in hydrochloric acid (Barshad, 1948); and the molybdenum was estimated by the thiocyanate-stannous chloride procedure described by Robinson (1948).

Table 2 shows the results of the two methods of analysis. The percent of ash in the plants (column 3) is included for the benefit of those who wish to compute the molybdenum on the air dry basis. Of the 16 samples analyzed, 3 show no difference, 11 agree within 0.25 microgram, and the remaining 2 differ by less than $1.0 \mathrm{mi}-$ crogram of molybdenum in the aliquot. Since the standards differ by $0.5 \mathrm{microgram}$, the agree ment is surprisingly good.

Table 2.--Determination of molybdenum in plants by laboratory and field methods

\begin{tabular}{|c|c|c|c|c|c|c|c|c|c|c|c|}
\hline \multirow[b]{3}{*}{ No. } & \multirow{3}{*}{\multicolumn{3}{|c|}{ Material }} & & & & \multicolumn{5}{|c|}{ Molybdenum Found } \\
\hline & & & & & & & \multicolumn{3}{|c|}{ Laboratory Method } & \multicolumn{2}{|c|}{ Field Method } \\
\hline & & & & & & & $\begin{array}{c}\text { Percent } \\
\text { ash }\end{array}$ & $\begin{array}{l}\text { Micrograms } \\
\text { in aliquot }\end{array}$ & $\begin{array}{l}\text { Percent } \\
\text { in ash }\end{array}$ & $\begin{array}{l}\text { Micrograms } \\
\text { in aliquot }\end{array}$ & $\begin{array}{l}\text { Percent } \\
\text { in ash }\end{array}$ \\
\hline 1 & $\begin{array}{l}\text { Woody aster. } \\
\text { Xylorhiza parryi }\end{array}$ & $\cdot \cdot$ & - $\cdot$ & $\cdot$ & $\cdot$ & - & 10.0 & 1.6 & 0.08 & 2.0 & 0.10 \\
\hline 2 & $\begin{array}{l}\text { Rabbitbrush. } \\
\text { Chrysothamnus sp. }\end{array}$ & $\cdots$. & - $\cdot$ & - & $\cdot$ & - & 7.0 & 2.8 & .012 & 3.5 & .014 \\
\hline 3 & $\begin{array}{l}\text { Pea vines } \\
\text { Pisum satinum }\end{array}$ & $\cdot \cdot$ & - . & $\cdot$ & $\therefore$ & $\therefore$ & 10.0 & 2.5 & .01 & 2. 5 & .01 \\
\hline 4 & $\begin{array}{l}\text { Saltbush } \\
\text { Atriplex canescens }\end{array}$ & $\cdot \cdot$ & - . & $\cdot$ & $\cdot$ & $\because$ & 15.0 & 1.2 & .005 & 1.0 & .004 \\
\hline 5 & $\begin{array}{l}\text { Cherrystone juniper } \\
\text { Juniperus monosperma }\end{array}$ & $\therefore$ & - $\therefore$ & $\therefore$ & - & - & 4.0 & .4 & .002 & .5 & .002 \\
\hline 6 & $\begin{array}{l}\text { Cherrystone juniper } \\
\text { Juniperus monosperma }\end{array}$ & . & $\cdot$. & $\cdot$ & - & $\cdot$ & 4. 5 & .3 & .001 & .25 & .001 \\
\hline 7 & $\begin{array}{l}\text { Cherrystone juniper. } \\
\text { Juniperus monosperma }\end{array}$ & a. & $\cdot$ & $\therefore$ & $\cdot$ & $\cdot$ & 5.0 & .2 & .001 & .1 & .001 \\
\hline 8 & $\begin{array}{l}\text { Alligator-barked juniper } \\
\text { Juniperus pachyphlaca }\end{array}$ & $\because$ & . & $\cdot$ & . & . & 5.0 & .35 & .002 & .1 & .001 \\
\hline 9 & $\begin{array}{l}\text { Shadscale. } \\
\text { Atriplex confertifolia }\end{array}$ & $\therefore$ & - $\cdot$ & $\cdot$ & $\cdot$ & $\cdot$ & 33.0 & .3 & .001 & .1 & .001 \\
\hline 10 & $\begin{array}{l}\text { Shadscale } \\
\text { Atriplex confertifolia }\end{array}$ & $\cdot \cdot$ & - $\cdot$ & $\cdot$ & $\cdot$ & $\bullet$ & 33.5 & .2 & .001 & .25 & .001 \\
\hline 11 & $\begin{array}{l}\text { Greasewood. } \\
\text { Sarcobatus vermiculatu }\end{array}$ & us & $\therefore$ & $\cdot$ & - & $\cdot$ & 26.5 & .25 & .001 & .4 & .002 \\
\hline 12 & $\begin{array}{l}\text { Tumblemustard } \\
\text { Sisymbrium linifolium }\end{array}$ & $\because$ & $\cdot$ & . & - & - & 7.0 & .25 & .001 & .25 & .001 \\
\hline 13 & $\begin{array}{l}\text { Alfalfa. } \\
\text { Medicago salisa } L .\end{array}$ & . & $\cdot$ & $\cdot$ & - & $\cdot$ & 8.0 & .22 & .001 & .2 & .001 \\
\hline 14 & $\begin{array}{l}\text { Milk vetch } \\
\text { Astragalus preussi arc }\end{array}$ & ctus & $\cdot$ & - & - & - & 24.0 & .1 & .001 & .25 & .001 \\
\hline 15 & $\begin{array}{l}\text { Yellow pine } \\
\text { Pinus'ponder'ose }\end{array}$ & $\therefore$ & . & $\cdot$ & - & $\cdot$ & 3.0 & $\therefore 1$ & .001 & .1 & .001 \\
\hline 16 & Fraxinus ànomala & $\cdot$ & $\cdot$ & . & - & - & 8.5 & .1 & .001 & .25 & .001 \\
\hline
\end{tabular}


These results indicate that this field method is satisfactory for the analysis of molybdenum in plants in biogeochemical prospecting. The equipment and reagents are inexpensive and readily obtainable. No special skills are required to perform the analysis. With a minimum of experience, one operator can analyse about 30 samples a day in an improvised field laboratory.

\section{REFERENCES CITED}

Barshad, Isaac, 1948, Molybdenum content of pasture plants in relation to toxicity to cattle: Soil Science, vol. 66, pp. 187-195.

Barshad, Isaac, 1949, Molybdenum determinations in plant material: Anal. Chemistry, vol. 21 , pp. 1148-50.

Bertrand, Didier, 1940, Contribution à L'Etude de la diffusion du molybdene chez les vegetaux: Inst. Pasteur Ann., vol. 64, pp. 90-96.

Evans, H. J., Purvis, E. R., and Bear, F. E. 1950 , Colorimetric determination of molybdenum by means of nitric and perchloric acid: Anal. Chemistry, vol. 22, pp. 1568-69.
Ferguson, W. S., Lewis, A. H., and Watson, S. J., 1940, The teart pastures of Somer set: Imp. Chem. Ind., Jealot's Hill Research Sta. Bull. 1, 28 pp.

Mitchell, R. L., 1948, Spectrographic analysis of soils, plants and related materials: Commonwealth Bur. Soil Sci. Tech. Comm. 44, p. 140.

Robinson, W. O., 1948, The presence and determination of molybdenum and rare earths in phosphate rock: Soil Science, vol. 66, pp. 317-322.

Robinson, W. O., and Edgington, Glen, 1948, Toxic aspect of molybdenum in vegetation: Soil Science, vol. 66, pp. 197-198.

Sandell, E. B., 1950, Colorimetric determination of traces of metals, 2nd Ed., Interscience Publishers Inc., New York, p. 455.

ter Meulen, H. and Ravenswaag, H. J., 1935, The molybdenum content of leaves: Royal Acad. Sci. Proc., vol. 38, pp. 7-10.

Ward, F. N., 1951, A seminicro method for field determination of molybdenum in soils and rocks: Anal. Chem., in press. 



\section{FILE COPY}

